\title{
A NOTE ON THE CURRENT STATE OF LEGISLATIVE PLANT PEST PROTECTION IN EU LAW
}

\author{
POZNÁMKA K AKTUÁLNEMU STAVU \\ LEGISLATÍVNEJ OCHRANY \\ PRED RASTLINNÝMI ŠKODCA V PRÁVE EÚ
}

\author{
Martin ILLÁŠ*
}

\section{Introduction}

On August 31st 2019, the deadline for Member States of the European Union to transpose the Commission Implementing Directive (EU) 2019/523 of 21 March 2019 amending Annexes I to V to Council Directive 2000/29/EC on protective measures against the introduction into the Community of organisms harmful to plants or plant products and against their spread within the Community (OJ L 86, 28.3.2019) (hereafter "Directive 2019/523") expired. The Slovak Republic failed to meet this deadline for several more or less serious reasons. Nevertheless, the Slovak Republic transposed Directive 2019/523 into its law by Regulation of the Government of the Slovak Republic No. 21/2020 Coll. Amending Regulation of the Government of the Slovak Republic No. 199/2005 Coll. on protective measures against the introduction and spread of organisms harmful to plants or plant products, as amended.

The failure to comply with the deadline for transposing Directive 2019/523 was caused by a number of factors consisting in the considerable scope of the legislation and its complexity

\section{Abstract (EN)}

The current developments in the European legislative protection against the introduction of plant pests is problematic in terms of its quality and in relation of the EU law to the law of EU Member States. The quality of this legislation is significant by non-uniform wording used in Directive 2019/523 and in Council Directive 2000/29/EC, especially in geographical indications, names of taxonomic units of organisms and listing of requirements, conditions, states, plants, plant products and organisms. Another problematic phenomenon of the uncertainty of the EU Member states caused by very slow European law-making process regarding to adoption of implementing regulations, which needed to enter into force on December 14th 2019 based on Regulation 2016/2031 repealing the present legislation in plant pest protection covered by seven older directives. Despite of this fact, the EU amended simultaneously this older legislation only a very short time before the date of repealing.

\section{Keywords (EN)}

plant pest protection, European legislative process, non-uniformity of legislative terms but also in the lack of clarity in certain parts of that legislation and in its relation to other legally binding acts of the European Union and the legal orders of the Member States.

The aim of this paper is to draw attention to the problematic developments in the current legislative protection against the introduction of plant pests both in terms of the quality of this legislation and in relation of the European Union law to the rights of the Member States of the European Union.

\section{Results and Discussion}

One of the factors mentioned is the considerable scope of the legislation, which follows directly from the scope of Directive 2019/523 and which, after transposition into the legal order of the Slovak Republic, amounts 183 pages of text. From the outset, this has been the reason for the lengthy nature of each stage of the legislative process in which the text underwent modifications, which was labour-intensive and time consuming.

\section{Abstrakt (SK)}

Súčasný vývoj európskej legislatívnej ochrany pred zavlečením rastlinných škodcov je problematický pokial' ide o kvalitu legislatívy ako aj vztah práva Európskej únie k právam členských štátov Európskej únie. Kvalita tejto legislatívy je poznačená nejednotnostou textov smernice ĚÚ) 2019/523 a smernice rady (ES) 2000/29/ES predovšetkým v geografických označeniach, taxonomických názvoch organizmov a uvádzania požiadaviek, podmienok, štátov, rastlín, rastlinných produktov a organizmov. Ďalším problematickým javom je neistota členských štátov Európskej únie zapríčinená velmi pomalým procesom európskej normotvorby pri prijatí vykonávacích nariadení, ktoré mali nadobudnút účinnost' 14. Decembra 2014 v nadväznosti na nariadenie (EÚ) 2016/2031, ktoré zrušilo dovtedajšiu legislatívnu ochranu pre rastlinnými škodcami upravenú siedmymi staršími smernicami. Napriek tejto skutočnosti Európska únia zároveň novelizovala túto staršiu legislatívu iba velmi krátko pred dátumom jej zrušenia.

\section{Klúčové slová (SK)}

ochrana pred rastlinnými škodcami, európska normotvorba, nejednotnost' legislatívnych pojmov

Ministry for Agriculture and Rural Development of the Slovak Republic, Slovakia 
However, the more complex factor was the content of the legislation itself and in particular the vast number of nonuniform and ambiguous wording used both in the text of Directive 2019/523 and in Council Directive 2000/29/EC of 8 May 2000 on protective measures against the introduction into the Community of organisms harmful to plants or plant products and against their spread within the Community (OJ L 169, 10.7.2000) (hereafter "Directive 2000/29"). This has made it difficult not only to transpose Directive 2019/523 but also to assess the context with the current wording of Directive 2000/29, on which Directive 2019/523 is dependent as an amendment.

These difficulties mainly concerned the following areas:

\section{Geographical indications}

The problematic terminology in this area concerns both the reference English text and the Slovak language version.

The text of Directive 2000/29 (as a generally binding legislation) lacks, beside other definitions, a clear definition of the term "third country". This term and its definition is important for the whole of Directive 2000/29, since it lays down various prohibitions and restrictions on imports of plants, parts of plants or plant products originating in the "third countries". Although it is clear from the context of the legislation that it is a country, which is not a Member State of the European Union, we do not find an explicit definition in Directive 2000/29. Even the Treaty on the Functioning of the European Union is not able to help us because it does not define this important term. However, the legislation should undoubtedly provide a clear definition of such an important concept.

In the text of Directive 2000/29, the distinction between the terms "non-European" ("neeurópsky") and "other than European" ("mimoeurópsky" alebo "iný než európsky") is not clear. It is apparent from several instances of the use of these terms that the term "other than European" ("iné než európske") refers only to the so-called "third countries" (as opposed to "European third countries"), but in many examples this is not the case, since the "third countries" are not mentioned. It is therefore not possible to determine unequivocally whether these terms regard the countries outside the European Union, countries outside the European continent or only third countries on the European continent. This is particularly problematic in classifying the Russian Federation and the Republic of Turkey in either of these categories, as both Russia and Turkey are located on two continents - Europe and Asia - so they can be described as "other than European countries", as "other than European third countries" but also as "non-European" countries.

The content of the term "Mediterranean" ("stredozemské" or "stredomorské") countries is unclear because the Directive 2000/29 does not define whether a country's Mediterranean location is determined, for example, by having a coastline on the Mediterranean or belonging to a Mediterranean geomorphological area, the Mediterranean phytogeographical area or an otherwise designated Mediterranean geographical area. This is particularly problematic in the classification of countries such as Northern Macedonia, Serbia, San Marino or Andorra, which belong to the geomorphologically and phytogeographically demarcated Mediterranean area, but are not the coastal states of the Mediterranean.

In addition to this factual content of the term, there is also the problem of its translation into Slovak in two forms "stredozemské" and "stredomorské", where it is not at all clear what reason for this duality the translation service of the European Commission had.

The content of the term "American continent" ("americký kontinent") is unclear because, according to the normal geographical understanding of the number of continents, there are two American continents (North America and South America). For this reason, there is no clear distinction between the terms 'American' and 'North America', since the term 'American' may refer to both the continents mentioned, or only to one of them, what is not clear from the term itself.

The term "South Africa" is unclear, as the Directive 2000/29 does not indicate whether it is a geographical area (i.e. the south of African continent) or a Republic of South Africa (i.e. the state defined by its borders). If it should be a geographical area of the south of African continent, then it is not clear by what and how this area is defined, i.e. whether it is a South African geomorphological region, a South African phytogeographical region, or an otherwise designated South African geographical region (for example, south of a designated parallel line). If it is to be only the Republic of South Africa, it is not clear why the Directive 2000/29 does not affect the also the states which form a single land unit with Republic of South Africa, i.e. Lesotho and Swaziland (i.e. an area with identical plant species and their pests).

Names of species, genera and other taxonomic units of plants and animals

Problems of this kind are caused solely by inconsistent and incorrect translation of Directive 2000/29 and Directive 2019/523 into Slovak.

In the Slovak language version, there is the designation "family nosáčikovité (Scolytidae)" and also the term "family podkôrnikovité (Scolytidae)". However, this is a mistake, because if it is to be a Scolytidae family it had to be translated as "podkôrnikovité". However, if it is to be a group of "nosáčikovité", it should be a subfamily Scolytinae. This discrepancy is not negligible since the Scolytinae subfamily includes about 6,000 species, while the Scolytidae family up to 60,000 species of beetles. However, the Directive 2000/29 in the English reference language contains only the designation of the family Scolytidae, what means "podkôrnikovité".

In the Slovak language version, the name of genus Prunus is used in many cases explicitly only for plum, although the genus Prunus also includes species such as cherry, sour cherry, peach, apricot, almond and others. It is therefore not clear in which cases all species of this genus Prunus should be concerned and in which cases only the plum. However, the Directive 2000/29 in the English reference language uses only the Latin generic name Prunus covering its all species.

\section{Requirements for approval processes and other import con- ditions}

This problematic texting concerns the individual conditions and requirements that have to be fulfilled when certain plants, plant parts and plant products are imported into the European 
Union, respectively to specific areas.

In the English reference text of Directive 2000/29 as well as in its Slovak language version, the word "except" ("okrem") is used differently with connection with the words "but including" ("ale vrátane"). This includes the listing of various commodities, plant genera and species or pest organisms, the listing of the various countries of origin of these commodities or the occurrence of species and organisms, as well as the conditions and import requirements. In many cases, it is not at all clear from the wording of Directive 2000/29 what constitutes an exception to the established list or an established rule when introduced by the word "except" and what, on the contrary, is covered by an established rule or is included in an established list when introduced by the words "but including".

In a large number of different requirements and conditions, which are usually listed in the Annexes to Directive 2000/29 in the right-hand column [as a rule in points (a), (b), (c) ....] or points [(i), (ii), (iii) ....], the conjunctions "and" ("a") and "or" ("alebo") are used opaque. In these cases, it is not possible to assess whether the stated conditions are to be met cumulatively or alternatively. This is particularly problematic in cases where part of the conditions or requirements stated are separated by the word "and" but some of them only by word "or". This brings chaos into the application of this legislation and collide with the legal certainty of the persons concerned who do not know whether they have or not have to meet the stated conditions at once or only some of them. Equally, the authorities are faced with the problem of requiring the fulfillment of all conditions together, or it is sufficient to fulfill one or only some of them, and if only some, which of them.

A very serious circumstance that the Slovak Republic had to take into account when transposing Directive 2019/523 is that a substantial part of the amended Directive 2000/29 including most of its annexes, as well as six other directives regulating plant pests and disease prevention measures and protection against their introduction into the European Union were repealed from December $14^{\text {th }} 2019$ by Regulation (EU) 2016/2031 of the European Parliament of the Council of 26 October 2016 on protective measures against pests of plants, amending Regulations (EU) No 228/2013, (EU) No 652/2014 and (EU) No 1143/2014 of the European Parliament and of the Council and repealing Council Directives 69/464/EEC, 74/647/EEC, 93/85/EEC, 98/57/EC, 2000/29/EC, 2006/91/ EC and 2007/33/EC (OJ L 317, 23.11.2016) (hereafter "Regulation 2016/2031"). However, Regulation 2016/2031 does not at all replace the numerous protective measures, lists of species and genera of organisms, plant commodities, the requirements and conditions laid down by the Directives repealed by it. Regulation 2016/2031 repealed these Directives almost without adoption or reception of their content (with the exception of some parts of the provisions of the repealed Directives), but did not oblige the Member States of the European Union to retain the existing legislative protection against the introduction of plant pests. The Member States of the European Union found themselves in a very uncertain situation, as they had to wait until the European Commission issues implementing regulations containing the legislation previously contained in the repealed Directives without any guarantee that it happens on December $14^{\text {th }} 2019$ at latest. These implementing regula- tions were published on December $10^{\text {th }}$ and $13^{\text {th }} 2019^{(1)}$, i.e. at the latest possible moment. Nevertheless, the Member States should as a reason of repealing the seven Directives referred to above including the Directive 2000/29 (repealed in most of its text), have started the legislative process of removing the transposed legislation from their own legal systems. This was, of course, unthinkable, as it could possibly cause the legislative vacuum and consequently allow the spread of plant pests, including quarantine ones. Therefore, depending on the adoption of the relevant implementing regulations for Regulation 2016/2031, it was not in the public interest to repeal national legislation by which Member States of the European Union, including the Slovak Republic, have transposed the seven abovementioned Directives repealed from December 14th 2019 by Regulation 2016/2031.

Another interesting circumstance the Slovak Republic had to take into account was that although it has been known since 2016 that Regulation 2016/2031 should repeal a substantial part of Directive 2000/29 with effect from December $14^{\text {th }} 2019$, the European Union in 2019 adopted an amendment to Directive 2000/29 (i.e. Directive 2019/523) with effect from August $31^{\text {st }}$ 2019. The Member States of the European Union therefore faced the task of extensively amending their national provisions transposing Directive 2000/29, although only three and a half months remained until the repeal of most of its provisions and annexes.

\section{Conclusions}

It is natural that if there is a need to regulate a particular area of social relations in a new or different way, irrelevant if in terms of content or form, or if the necessity and urgency of the situation requires, new legislation should be adopted. This applies to any legal order, i.e. also to European Union law. However, in the circumstances described above when the new legislation is in force for several years and its legisvacant period is just before its expiry, and despite of that a sudden and extensive amendment to the old legislation is adopted, the question arises what is the substance and practical purpose and meaning of such a European law-making and whether it is fair to all addressees of this legislation. It is clear that the impact this European law-making has on the legal certainty of the undertakers concerned and the competent authorities of the Member States is not positive. Not to mention the risk of the serious threat to the public interest in the protection against the introduction of plant pests into the European Union as a result of the uncer-

(1) Commission Implementing Regulation (EU) 2019/2072 of 28 November 2019 establishing uniform conditions for the implementation of Regulation (EU) 2016/2031 of the European Parliament and the Council, as regards protective measures against pests of plants, and repealing Commission Regulation (EC) No 690/2008 and amending Commission Implementing Regulation (EU) 2018/2019 (OJ L 319, 10.12.2019). Commission Implementing Regulation (EU) 2019/2148 of 13 December 2019 on specific rules concerning the release of plants, plant products and other objects from quarantine stations and confinement facilities pursuant to Regulation (EU) 2016/2031 of the European Parliament and of the Council (OJ L 325, 16.12.2019). 
tainty in repealing of the old and adoption of the new legislative protection against this risk.

Therefore, the Slovak Republic as a Member State of the European Union, cannot be denounced for the breach of European law if, despite its obligation under the Treaty on the Functioning of the European Union, it proceeds very carefully and reservedly to transpose the Directive 5019/523, which will soon become invalid. Similarly, no Member State can be criticized if it does not intend to take the risk of creating a legislative vacuum in such an important area as protection against the introduction of plant pests because of the non-conceptual and slow European law-making process.

\section{Contact address/ Kontaktná adresa}

Mgr. Martin Illáš

Ministry for Agriculture and Rural Development of the Slovak Republic

Dobrovičova 12, 81266 Bratislava

tel.: +421599266 404

e-mail:martin.illas@land.gov.sk 